\title{
Evaluation of the acute toxicity, phototoxicity and embryotoxicity of a residual aqueous fraction from extract of the Antarctic moss Sanionia uncinata
}

Andréia da Silva Fernandes ${ }^{1 *}$, Lara Barroso Brito², Gisele Augusto Rodrigues Oliveira², Elisa Raquel Anastácio Ferraz ${ }^{3}$, Heitor Evangelista ${ }^{4}$, José Luiz Mazzei ${ }^{5}$ and Israel Felzenszwalb ${ }^{1}$

From 2nd Latin American Congress of Clinical and Laboratorial Toxicology

Porto Alegre, Brazil. 3-6 June 2018

\begin{abstract}
Background: Ultraviolet (UV) radiation is the main exogenous inductor of skin damage and so photoprotection is important to control skin disorders. The Antarctic moss Sanionia uncinata is an important source of antioxidants and the photoprotective activity of its organic extracts has been investigated. This study aimed to evaluate the potential photoprotection, cytotoxicity and embryotoxicity of residual aqueous fraction (AF) from the moss S. uncinata.
\end{abstract}

Methods: UV-visible spectrum and SPF (sun protection factor) were determined by spectrophotometry. Embryotoxicity potential was evaluated by Fish embryo-larval toxicity test using zebrafish (Danio rerio) as organism model. Cell death assays by water-soluble tetrazolium salt (WST-1) and lactate dehydrogenase (LDH) were investigated using HaCaT keratinocyte cell line cultured in monolayers and three dimensions (3D). Phototoxicity and association with UV-filters were performed by $3 T 3$ neutral red uptake test.

Results: The AF showed sharp absorption bands in the UV region and less pronounced in the visible region. The SPF was low ( $2.5 \pm 0.3)$, but the SPF values of benzophenone- 3 and octyl-methoxycinnamate increased $\sim 3$ and 4 times more, respectively, in association with AF. The AF did not induce significant lethal and sublethal effects on zebrafish early-life stages. In monolayers, the HaCaT cell viability, evaluated by WST-1, was above $70 \%$ by $\leq 0.4 \mathrm{mg} \mathrm{AF} / \mathrm{mL}$ after 48 and $72-\mathrm{h}$ exposure, whereas $\leq 1 \mathrm{mg} \mathrm{AF} / \mathrm{mL}$ after $24-\mathrm{h}$ exposure. The LDH assay showed that the cell viability was above $70 \%$ by $\leq 0.4 \mathrm{mg} \mathrm{AF} / \mathrm{mL}$ even after 72-h exposure, but $\leq 1 \mathrm{mg} / \mathrm{mL}$ after 24 and 48-h exposure. In 3D cell culture, an increased cell resistance to toxicity was observed, because cell viability of HaCaT cell by WST-1 and LDH was above $90 \%$ when using $\leq 1$ and $4 \mathrm{mg} \mathrm{AF} / \mathrm{mL}$, respectively. The AF demonstrated values of photo irritation factor $<2$ and of photo effect $<0.1$, even though in association with UV-filters.

Conclusions: The residual AF absorbs UV-vis spectrum, increased SPF values of BP-3 and OMC and does not induce embryotoxicity to zebrafish early life-stage. The cell death assays allowed establishing non-toxic doses of AF and phototoxicity was not detected. AF of S. uncinata presents a good potential for skin photoprotection against UV-radiation.

Keywords: Sanionia uncinata, Sun protection factor, Embryotoxicity, Cell death, 3D cell, Phototoxicity

\footnotetext{
* Correspondence: andreiadasilvaf@gmail.com

'Laboratory of Environmental Mutagenesis, Department of Biophysics and

Biometry, University of the State of Rio de Janeiro, Rio de Janeiro, RJ, Brazil

Full list of author information is available at the end of the article
}

(c) The Author(s). 2019 Open Access This article is distributed under the terms of the Creative Commons Attribution 4.0 International License (http://creativecommons.org/licenses/by/4.0/), which permits unrestricted use, distribution, and reproduction in any medium, provided you give appropriate credit to the original author(s) and the source, provide a link to the Creative Commons license, and indicate if changes were made. The Creative Commons Public Domain Dedication waiver (http://creativecommons.org/publicdomain/zero/1.0/) applies to the data made available in this article, unless otherwise stated. 


\section{Background}

The human incidences of skin cancer and photoaging, that result from the excessive solar ultraviolet radiation (UVR) exposure, are increasing around the world [1]. The UVR is classified into UVA (from 315 to $400 \mathrm{~nm}$ ), UVB (from 280 to $315 \mathrm{~nm}$ ) and UVC (from 100 to 280 $\mathrm{nm}$ ) [2]. Acute and chronic skin exposures to UVR result in deleterious effects on human skin such as erythema, photo-ageing and initiation of carcinogenic processes [3]. In general, sunscreens are intended to protect the surface of the skin by reflecting (inorganic UV filters) or absorbing (organic UV filters) radiation [4]. However, recent publications have shown that more commonly used topical sunscreens do not provide full protection, failing to act on relevant biochemical events, as degradation of the extracellular matrix, immunosuppression, inhibition on the release of reactive oxygen species (ROS) and of reactive nitrogen species $[5,6]$. Moreover, some UV-filters can diffuse into deep layers of the skin and the systemic absorption can result in efficiency loss and local and systemic toxicity [7].

The use of natural antioxidant agents, such as phenolic compounds especially flavonoids present in plant kingdom, might be an effective strategy for minimize the deleterious effects of UV-induced reactive species. These compounds have been used in topical cosmetic formulations by the pharmaceutical industry [8], because flavonoids are structurally similar to chemical filters which makes it susceptible to absorption of UVR. The association of natural products with sunscreen products can extend the benefits of solar protection by offering additional features that minimize damage in tissues chronically exposed to UVR [9].

The Antarctica moss Sanionia uncinata (Hedw.) Loeske from King George Island is directly exposed to high levels of solar radiation during the summer (December to late March), when soil and air temperatures typically remain above freezing. At sub-Antarctic islands such as the collection site, UVR levels reaching the surface are about four times higher in the summer (in terms of maximum daily UV index) than in the winter or autumn [10]. The influence of the Antarctic ozone hole on surface climate is most pronounced during the austral summer season [11]. Due to this, Antarctic S. uncinata has been exposed to greater solar UVR and consequently it has tolerated and acclimatized well to that singular environmental stresses, possibly via increase in the synthesis of important constituents for protecting, such as flavonoids [12].

Our research group has showed that aqueous and hydroethanolic (HE) extracts from S. uncinata act as protectors against plasmid DNA cleavage by way of scavenging of superoxide radical anion and hydroxyl radical [10], and do not induce point mutations [13]. Nevertheless, these extracts induced an increase in DNA cleavage via a Fenton-like reaction [10]. We also demonstrated that the inhibition of ROS-damage by S. uncinata has been associated with the flavonoid constituents such as flavone, flavanone, flavonols, chacones and catechin [14]. We also demonstrated that HE, ethanolic (EE) and methanolic (ME) extracts showed high sun protection factor (SPF) and enhanced SPF of benzophenone-3 (BP3 ), indicating that their constituents could be considered as attractive candidates for protection against UVinduced erythema formation. Besides, HE, EE and ME did not induce photomutation and showed photoprotection against the photobiological and ROS-inducing effects of the UVA radiation [14].

Since $S$. uncinata extracts, principally HE, present potential photoprotection against UV damage and, consequently have been considered as an attractive candidate for cosmetic and dermatological applications, the present study aimed to evaluate the potential photoprotection, cytotoxicity and embryotoxicity of an aqueous fraction (AF) from HE of the polar moss S. uncinata.

\section{Methods \\ Moss material and liquid-liquid partitioning}

Samples of S. uncinata were collected in the vicinity of the Brazilian Comandante Ferraz Antarctic Station $\left(62^{\circ} 05^{\prime} \mathrm{S}, 58^{\circ} 24^{\prime} \mathrm{W}\right)$ in King George Island, located in the South Shetland Islands, Antarctic Peninsula in January 2012, using aseptic procedures, storing in plastic bags and keeping frozen until being processed in laboratory conditions. The specimens were identified by Prof. Dr. Antônio Batista Pereira from the Federal University of Pampa, Rio Grande do Sul (Brazil), and a voucher specimen was deposited in the Herbarium of the State University of Rio de Janeiro, Brazil, under the registration number H-RJ 11,811. The collection of sample material was authorized by the Brazilian Ministry of the Environment.

Preparation of the raw hydroethanolic extract was previously described in detail by our group [14]. A portion $(1 \mathrm{~g})$ of the dried hydroethanolic extract was solubilized in $30 \mathrm{~mL}$ of water: methanol solution $(7,3)$ and was fractionated by sequential liquid-liquid partition $(10 \mathrm{~mL}$ each solvent) with $n$-hexane (Hf), dichloromethane (Df), ethyl acetate (Ef), $n$-butanol (Bf), remaining the residual aqueous fraction (AF). The extractive solvents were removed using a rotary evaporator under reduced pressure at $40{ }^{\circ} \mathrm{C}$ and the fractions were frozen and lyophilized to remove the remaining water. The yields (w/w) of dried partition fractions were 6.13, 8.63, 7.50, 22.33 and $62.43 \%$, respectively, for $\mathrm{Hf}, \mathrm{Df}, \mathrm{Ef}, \mathrm{Bf}$ and $\mathrm{AF}$.

\section{UV-visible spectrophotometry}

An aliquot of $200 \mu \mathrm{L}$ of AF solution $(0.25 \mathrm{mg} / \mathrm{mL})$ in isopropanol were transferred to a 96-well microplate and 
the absorption spectrum was read at $10 \mathrm{~nm}$ intervals from 200 to $800 \mathrm{~nm}$ using a microplate reader ( $\mu$-Quant, Biotek, USA).

\section{In vitro sun protection factor}

In vitro SPF was determined and calculated according to previously described protocols [14-16] using two assays. In the first assay, $200 \mu \mathrm{L}$ of $\mathrm{AF}$ solution $(1 \mathrm{mg} / \mathrm{mL}$ in isopropanol) or UV-filters (BP-3 at $50 \mu \mathrm{g} / \mathrm{mL}$; 3 -(4 methylbenzylidene)-camphor (MBC) at $10 \mu \mathrm{g} / \mathrm{mL}$; octylmethoxycinnamate $(\mathrm{OMC})$ at $0.01 \mu \mathrm{L} / \mathrm{mL}$ and octocrylene $(\mathrm{OCT})$ at $0.08 \mu \mathrm{L} / \mathrm{mL}$ ) were transferred to a 96-well microplate. In the second assay, $100 \mu \mathrm{L}$ of the fraction and $100 \mu \mathrm{L}$ of UV-filters were mixed in wells of a 96well microplate. Subsequently, spectrophotometric scanning was performed at wavelengths between 290 and $320 \mathrm{~nm}$, with intervals of $5 \mathrm{~nm}$, using $\mu$-Quant microplate reader. The linearity of the reading ranges at each wavelength was previously checked with the calibration curves of UV-filters solutions at 10, 25, 30, 50 and $100 \mu \mathrm{g} / \mathrm{mL}$ and correlation coefficients higher than 0.99 were reached. The SPF was calculated according to the Mansur et al. [17]:

$$
\mathrm{SPF}=\mathrm{CF} \times \Sigma[\mathrm{E}(\lambda) \times \mathrm{I}(\lambda) \times \mathrm{AU}(\lambda)]
$$

in which $E(\lambda)$ is the erythmogenic effect of the radiation, $I(\lambda)$ the sunlight intensity and $A U(\lambda)$ the absorbance. The values of $E(\lambda)$ multiplied by $I(\lambda)$ are normalized constants at each interval of $5 \mathrm{~nm}$ within the wavelength range measured and are given by Sayre et al. [18]. CF is a correction factor equal to 10 .

\section{Fish embryo-larval toxicity (FET) test}

Adult male and female zebrafish (Danio rerio) were obtained from a commercial supplier and kept in separate tanks (ethical approval UFG No. 102/2014). Fish culture and maintenance conditions were previously described by our group [19]. The fish embryo toxicity test with zebrafish was carried out according to OECD Test Guideline (TG) 236 [20] with some modifications such as test chambers (96-well plate) and volume to cover eggs $(200 \mu \mathrm{L} /$ well $)$. Zebrafish eggs were collected approximately $30 \mathrm{~min}$ after natural mating, rinsed in water, and examined under a stereomicroscope (Bel Photonics STM PRO, Milano, Italy). Unfertilized or injured eggs were discarded. The fertilization success was checked, and only batches of eggs with fertilization rate above $90 \%$ were used. Twenty fertilized eggs per concentration were randomly selected and carefully distributed to a 24-well plate, filled with $2 \mathrm{~mL}$ of different concentrations of AF $(0.01,0.1,1,10$ e $100 \mathrm{mg} / \mathrm{L})$ or negative (NC; maintenance water) and positive controls (PC; 3,4- dichloroaniline at $4.0 \mathrm{mg} / \mathrm{L}$ ). Four fertilized eggs were used as internal plate control (maintenance water) on each test and control groups. The test was performed in a climate chamber at $26 \pm 1{ }^{\circ} \mathrm{C}$ and 12-h light. Neither food nor aeration was provided during the assays. Embryo development was assessed at 24, 48, 72, and 96-h post-fertilization using a stereomicroscope. The distinction between the normal and abnormal development of embryos was established according to the zebrafish development descriptions reported by Kimmel et al. [21]. Lethal (egg coagulation, no somite formation, non-detachment of the tail from yolk sac, and no heart beating) and sublethal (effects on the eye and body pigmentation, absorption of the yolk sac, hatching rate, swimming bladder inflation, otolith, presence of edemas and blood accumulation, tail deformities) parameters were observed and reported.

\section{Alginate encapsulation of $\mathrm{HaCaT}$ cells and spheroid formation}

Human keratinocyte cells $(\mathrm{HaCaT})$ were acquired from the Cell Bank of Rio de Janeiro (Rio de Janeiro, Brazil). Dulbecco's Modified Eagle's Medium (DMEM) (Life technologies, New York, USA) completed with $10 \%$ of fetal bovine serum (FBS) and 1\% of antibiotic solution (100 IU/ $\mathrm{mL}$ penicillin to $100 \mu \mathrm{g} / \mathrm{mL}$ streptomycin, Life, USA) was used to grow the cells at $37^{\circ} \mathrm{C}$ and $5 \% \mathrm{CO}_{2}$ in humid atmosphere. The $3 \mathrm{D}$ cell culture was carried out according to Ferraz et al. [22, 23]. Briefly, after approximately $80 \%$ confluence in a monolayer culture, $\mathrm{HaCaT}$ cells were trypsinized and resuspended at a density of $5 \times 10^{5}$ cells $/ \mathrm{mL}$ in a $1.2 \%$ alginate MVM solution (Pronova, UP MVM, Novamatrix, Sandvika, Norway). Using a syringe attached to a 21-gauge needle, the mixture of alginate and cells was placed into a beaker containing $25 \mathrm{~mL}$ of $102 \mathrm{mM} \mathrm{CaCl}_{2}$ (Sigma, St. Louis, MO), forming alginate scaffolds containing approximately 20,000 cells within. The scaffolds were washed twice with $0.9 \% \mathrm{NaCl}$, once with complete medium, and then cultured in 6-well plates at $37^{\circ} \mathrm{C}$ and $5 \% \mathrm{CO}_{2}$ for 4 days with medium replaced all days until cell spheroids were formed. The details about the count of cells within the scaffold were previously described in detail by our group [23].

\section{Treatment of cells with residual aqueous fraction (AF)}

About $2 \times 10^{4} \mathrm{HaCaT}$ cells grown in monolayers and aggregated into spheroids in 3D alginate scaffolds were seeded into each well of a sterile flat-bottomed 96-well plate, and incubated with $0.4 \mu \mathrm{g} / \mathrm{mL}$ to $10 \mathrm{mg} / \mathrm{mL} \mathrm{AF}$ (diluted in DMEM supplemented with 10\% FBS) for 24 , 48 or 72 -h. DMEM supplemented with $10 \%$ FBS was used as the negative control and $2 \%$ Triton-X100 as the positive control. 


\section{WST-1 assay}

The water-soluble tetrazolium salt assay (WST-1) was used to determine the number of viable cells after exposure to AF. Briefly, after treatment, the culture medium was replaced by $90 \mu \mathrm{L}$ fresh culture medium and $10 \mu \mathrm{L}$ WST-1 reagent (4-[3-(4-iodophenyl)-2-(4-nitrophenyl)2H-5-tetrazolium]-1,3-benzene disulfonate) (Roche Co., South San Francisco, CA) and incubated at $37{ }^{\circ} \mathrm{C}$ and $5 \%$ $\mathrm{CO}_{2}$ for 3-h. The absorbance was then measured at 450 $\mathrm{nm}$ using a Polaris Microplate Reader (Celer, Brazil) according to the kit protocol. The intensity of the yellow color in the negative control wells was designated as $100 \%$ viability and all further comparisons were based upon this reference level.

\section{Lactate dehydrogenase (LDH) activity assay}

After AF treatment, the integrity of the cell membrane was evaluated by measuring release of intracellular $\mathrm{LDH}$ which reduces $\mathrm{NAD}^{+}$to $\mathrm{NADH}^{+} / \mathrm{H}^{+}$by oxidation of lactate to pyruvate. Two hydrogen radicals released react with tetrazolium salt to yield a red formazan salt. The LDH cytotoxicity assay was carried out according to the manufacturer's instructions (Roche, Mannheim, Germany). Briefly, $100 \mu \mathrm{L}$ supernatant and $100 \mu \mathrm{L}$ reaction mixture (freshly prepared) were transferred from each well of a 96-well flat-bottomed plate. The plates were incubated for $30 \mathrm{~min}$ at $20^{\circ} \mathrm{C}$ in the dark and absorbance was measured at $492 \mathrm{~nm}$ using a Polaris Microplate Reader. Blank values indicating the absorbance of the LDH were subtracted from all samples. The percent cytotoxicity was calculated according to the kit protocol.

\section{In vitro 3T3 NRU phototoxicity assay}

The experiment of in vitro 3T3 NRU assay was carried out according to OECD guideline [24]. The mouse fibroblast cell line, Balb/c 3T3, clone 31, was acquired from the Cell Bank of Rio de Janeiro (Rio de Janeiro, Brazil). The cells were cultivated in DMEM containing 10\% fetal calf serum (FCB), 1\% glutamine and $1 \%$ penicillin and streptomycin. About $1 \times 10^{4}$ BALC/c cells per well were seeded in two 96-well microplates containing DMEM supplemented with 10\% FCB and cultured overnight. Cells were then exposed to dilutions $(7.81,15.62,31.25,62.5,125,250,500,1000 \mu \mathrm{g} / \mathrm{mL})$ of the AF and/or UV filters (BP-3, MBC, OMC and OCT) in Earle's Balanced Salt Solution for $60 \mathrm{~min}$. After the cells were irradiated at dose of $5 \mathrm{~J} / \mathrm{cm}^{2}\left(1.7 \mathrm{~mW} / \mathrm{cm}^{2}\right)$ for $50 \mathrm{~min}$ using a UV Crosslinker (Ultra-violet Products Ltd., Upland, CA) model CL-1000 L (365 nm). After UV exposure, the test solution was replaced by fresh medium. Non-irradiated plate was kept at room temperature in a dark environment for $50 \mathrm{~min}$. Cytotoxic effects were determined 24-h later by measuring the neutral red uptake (NRU). Neutral red (NR) solution $(50 \mu \mathrm{g} / \mathrm{mL})$ was added to the cell cultures $(100 \mu \mathrm{L}$ per well $)$ and incubated for $3 \mathrm{~h}$ at $37^{\circ} \mathrm{C}$. The cells were then washed with PBS and the neutral red dye was extracted from the lysosomes using NR desorb solution (freshly prepared water + ethanol + acetic acid 49:50:1). Uptake of dye was measured spectrophotometrically at $540 \mathrm{~nm}$ using $\mu$-Quant microplate reader. Tetracycline was used as a positive control (1.87$30 \mu \mathrm{g} / \mathrm{mL}$ under UVR and $100-1000 \mu \mathrm{g} / \mathrm{mL}$ without UVR). Sodium lauryl sulfate was used as a negative control (20$100 \mu \mathrm{g} / \mathrm{mL}$ ). Photo Irritation Factor (PIF) and Mean Photo Effect (MPE) were calculated using Phototox 2.0 software. According to the OECD TG 432 [24], a test substance with a $\mathrm{PIF}<2$ or $\mathrm{MPE}<0.1$ is predicts as no phototoxic. A PIF $>2$ and $<5$ or MPE $>0.1$ and $<0.15$ is predicts as probable phototoxicity and a PIF $>5$ or MPE $>0.15$ predicts as positive phototoxicity.

\section{Statistical analysis}

The significance of differences was calculated using oneway ANOVA and Dunnett's post hoc test. In vitro FPS was analyzed by the $t$-Student test. The graphics and all statistical analyzed were performed using GraphPad Prism. All the experiments were carried out in triplicate and repeated twice. The data were expressed as mean \pm standard deviation. $P<0.05$ were considered statistically significant.

\section{Results}

\section{UV-vis analysis}

The absorption spectrum of AF at UV-visible light is shown in Fig. 1. This residual aqueous fraction absorbs in the spectral range of 200 to $700 \mathrm{~nm}$, with maximum wavelength $\left(\lambda_{\max }\right)$ at $220 \mathrm{~nm}$. Other lesser intense absorption bands (of $\lambda \max 270,350,420,500$ and $650 \mathrm{~nm}$ ) were also detected.

\section{In vitro SPF}

The SPF values obtained at $2 \mathrm{mg} / \mathrm{mL}$ was $2.5 \pm 0.3$ (Table 1). Except for MBC and OCT that have an expected natural additive increasing on absorption intensity, the association of AF with BP-3 and OMC led to a significant higher increase $(P<0.05, t$-Student) of SPF values: $12.3 \pm 0.9$ for $\mathrm{BP}-3$ increased to $18.0 \pm 1.2$, equivalent to $\sim 3$-fold increasing; $17.6 \pm 0.8$ for $\mathrm{OMC}$ increased to $24.5 \pm 0.7$ equivalent to $\sim 4$-fold increasing. The significant synergic effect between the AF and these UV-filters can be seen in the Fig. 2, in which are represented the calculated $\mathrm{E} \times \mathrm{I} \times \mathrm{AU}$ curves of $\mathrm{AF}+\mathrm{BP}-3$ and $\mathrm{AF}+\mathrm{OMC}$ mixtures determined from observed absorption and by predicting if only additive absorption would be presented.

\section{Fish embryo-larval acute toxicity test}

The embryotoxicity of different concentrations (0.01 to 100 $\mathrm{mg} / \mathrm{L}$ ) of AF processes on zebrafish early-life stage was 


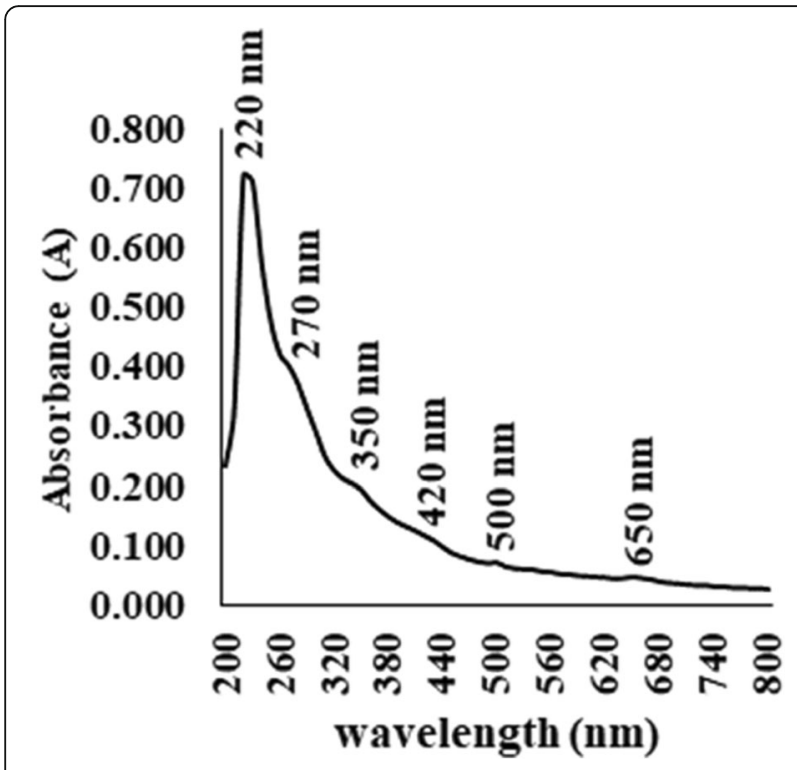

Fig. 1 UV-VIS spectrum of the residual aqueous fraction (AF) from hydroalcoholic extract of the polar moss Sanionia uncinata

recorded at 24, 48, 72 and 96-h. No significant lethal or sublethal effect was observed for AF during 96-h of exposure. Figure 3 shows survival rate on zebrafish early-life stages after 24, 48, 72 and 96-h of exposure. Besides, hatching rate of embryos was not affected by AF until 96-h, as well as did not cause any significant malformations in zebrafish until 96-h of exposure compared to negative control that exhibited a normal embryonic development (Fig. 4a and b). Thus, it seems to have no embryotoxic potential in this concentration range.

\section{WST-1 and LDH assays - monolayers and 3D cells}

Figure 5 shows the influence of AF on the viability of mitochondrial dehydrogenase activity and on cell

Table 1 Absorbances of residual AF from hydroalcoholic extract of Sanionia uncinata and the spectrophotometrically calculated SPF

\begin{tabular}{llllll}
\hline (nm) & AF & \multicolumn{4}{l}{ AF plus UV-filters } \\
\cline { 3 - 6 } & & BP-3 & MBC & OMC & OCT \\
\hline 290 & $0.33 \pm 0.03$ & $2.40 \pm 0.14$ & $2.57 \pm 0.04$ & $2.32 \pm 0.07$ & $2.59 \pm 0.12$ \\
295 & $0.30 \pm 0.03$ & $2.16 \pm 0.14$ & $2.72 \pm 0.04$ & $2.41 \pm 0.07$ & $2.67 \pm 0.12$ \\
300 & $0.27 \pm 0.03$ & $1.90 \pm 0.13$ & $2.75 \pm 0.04$ & $2.44 \pm 0.07$ & $2.70 \pm 0.12$ \\
305 & $0.24 \pm 0.02$ & $1.72 \pm 0.12$ & $2.64 \pm 0.03$ & $2.47 \pm 0.07$ & $2.66 \pm 0.12$ \\
310 & $0.22 \pm 0.02$ & $1.64 \pm 0.11$ & $2.45 \pm 0.03$ & $2.52 \pm 0.07$ & $2.60 \pm 0.12$ \\
315 & $0.20 \pm 0.02$ & $1.63 \pm 0.10$ & $2.13 \pm 0.03$ & $2.40 \pm 0.07$ & $2.45 \pm 0.12$ \\
320 & $0.19 \pm 0.02$ & $1.63 \pm 0.10$ & $1.70 \pm 0.02$ & $2.14 \pm 0.06$ & $2.25 \pm 0.11$ \\
SPF & $2.5 \pm 0.3$ & $18.0 \pm 1.2^{*}$ & $25.8 \pm 0.3$ & $24.5 \pm 0.7^{*}$ & $26.4 \pm 1.2$
\end{tabular}

Sun Protection Factor (SPF) of UV-filters: benzophenone-3, BP-3 (12.3 \pm 0.9$) ; 3-$ (4-methylbenzylidene)-camphor MBC (24.8 \pm 1.4$)$; octyl-methoxycinnamate, OMC (17.6 \pm 0.8$)$; and octocrylene, OCT (22.6 \pm 0.1$)$; AF: aqueous fraction;

"Synergistic effect compared to the respective UV-filters $(P<0.05, t$-Student)

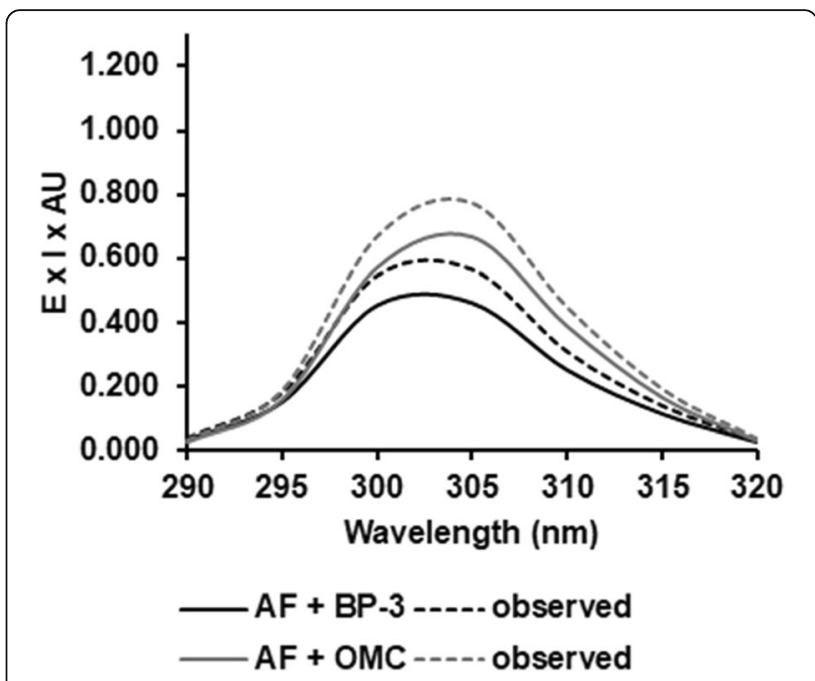

Fig. 2 Relationship between erythmogenic effect of the radiation (E), sunlight intensity and (I) and absorbance (AU) with wavelength range. AF: aqueous fraction; $\mathrm{BP}-3$ : benzophenone-3;

OMC: octyl-methoxycinnamate

membrane integrity of $\mathrm{HaCaT}$ keratinocyte cell line cultured in monolayers after 24, 48 and 72-h of incubation. In monolayers, the $\mathrm{HaCaT}$ cell viability evaluated by WST- 1 was above $70 \%$ by $\leq 0.4 \mathrm{mg} \mathrm{AF} / \mathrm{mL}$ after 48 and 72-h exposure, whereas was $\leq 1 \mathrm{mg}$ AF/ $\mathrm{mL}$ after 24-h exposure. The LDH assay showed that the cell viability was above $70 \%$ by $\leq 0.4 \mathrm{mg} \mathrm{AF} / \mathrm{mL}$ even after 72 - $\mathrm{h}$ exposure, but was $\leq 1 \mathrm{mg} / \mathrm{mL}$ after 24 and 48-h exposure (Fig. 5). In 3D cell culture (Fig. 6), an increased cell resistance to toxicity was observed, because viability of $\mathrm{HaCaT}$ cells by WST-1 and LDH was above $\sim 90 \%$ when using $\leq 1$ and $4 \mathrm{mg} \mathrm{AF} / \mathrm{mL}$, respectively, in all exposure times.

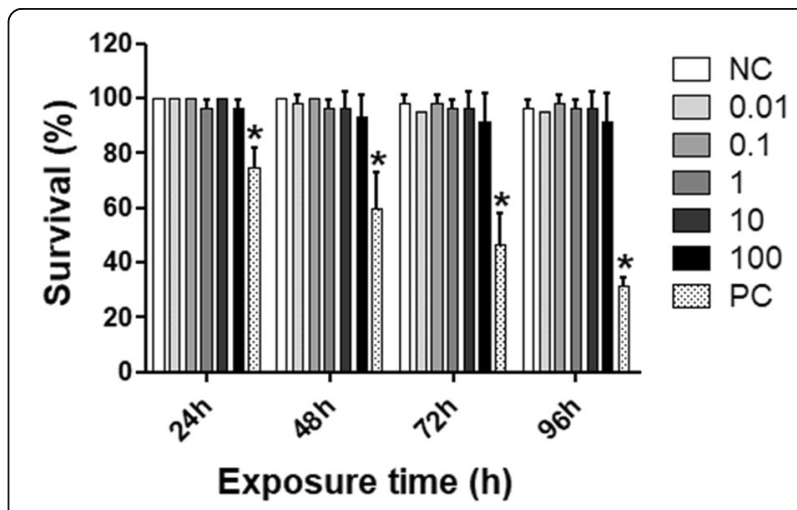

Fig. 3 Percentage of survival on zebrafish early-life stage after 24, 48, 72 , and $96-\mathrm{h}$ of aqueous fraction (AF) from extract of the Antarctic moss Sanionia uncinata exposure (0.01 to $100 \mathrm{mg} / \mathrm{L}$ ). Bars represent the mean \pm standard deviation. ${ }^{*} P<0.001$ statistically different from the respective negative control. $\mathrm{NC}=$ negative control (maintenance water); $\mathrm{PC}=$ positive control (3,4-dichloroaniline at $4.5 \mathrm{mg} / \mathrm{L})$ 
(a)

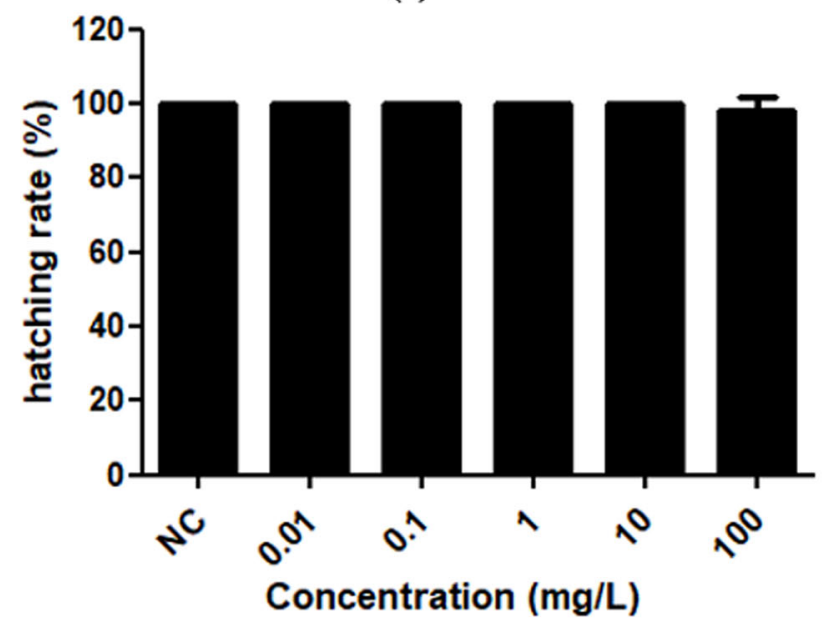

(b)

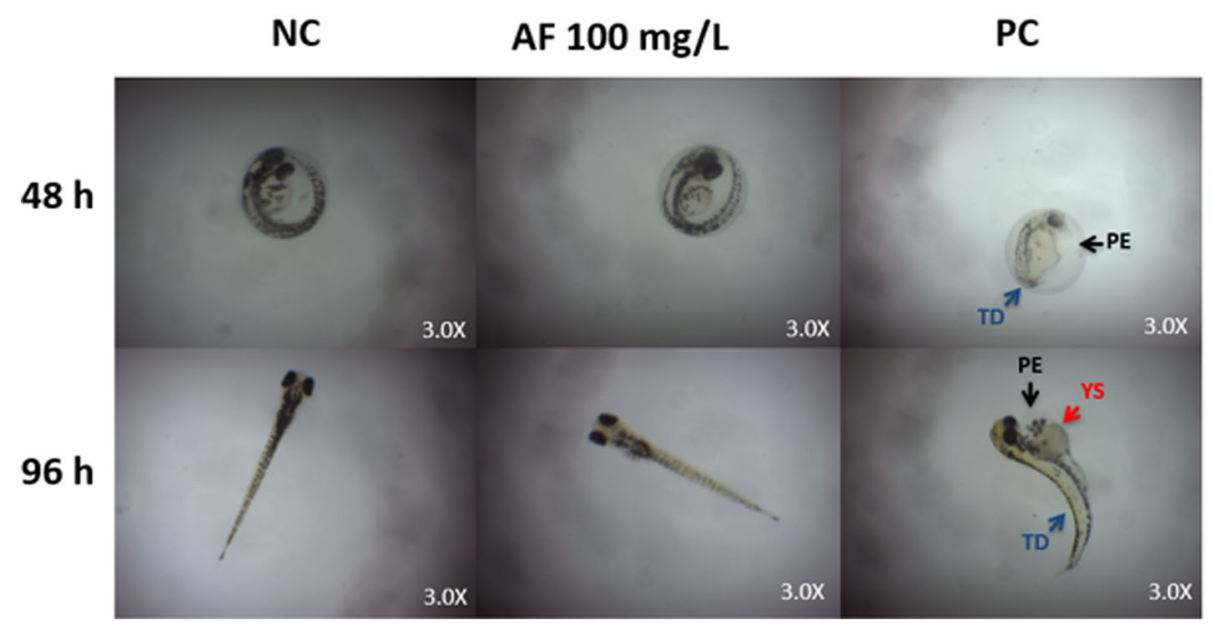

Fig. 4 a Effects of the aqueous fraction (AF) from extract of the Antarctic moss Sanionia uncinata on hatching success of zebrafish embryos. Bars represent the mean \pm standard deviation. The values do not differ significantly from each other $(P>0.001)$. b Representative photomicrographs of the absence of abnormalities in zebrafish at early life-stage induced by AF during 96-h of exposure. NC: negative control; PC: positive control; PE: pericardial edema; tail deformation (TD) and YS: delayed yolk sac absorption

\section{In vitro 3 T3 NRU assay}

There is consensus in the classification of phototoxic potential of AF and its association with different UV-filters using either the PIF or MPE grading schemes in the 3T3 NRU testing results (Table 2). AF was considered no phototoxic, since it presented mean PIF of 1.089 and mean MPE of 0.035. In combinations with UV-filters the AF did not also present any phototoxic potential (PIF $<2$ and MPE $<0.1)$.

\section{Discussion}

Our research group has previously reported important photoprotective properties of extracts from Antarctic moss $S$. uncinata, as well as its toxicological activities of its organic extracts. We have also demonstrated positive correlation between protective effect against UVR and phenolic compound present in extracts. Waterextractable compounds seem to contribute on photoprotection of this Antarctic moss [10, 13, 14]. Given the above context, the goal of this paper is to explore the potential photoprotective, cytotoxic and embryotoxic effects of residual AF from the polar moss S. uncinata. This fraction, was obtained through the liquid-liquid partitioning of the HE of this moss. The UV-visible spectrum showed that AF absorbs in the UV-visible light spectra. AF exhibits UV peaks absorption (200-420 nm) similar to the major flavonoids such as aurones, chalcones, flavones and flavanols [25]. These results 

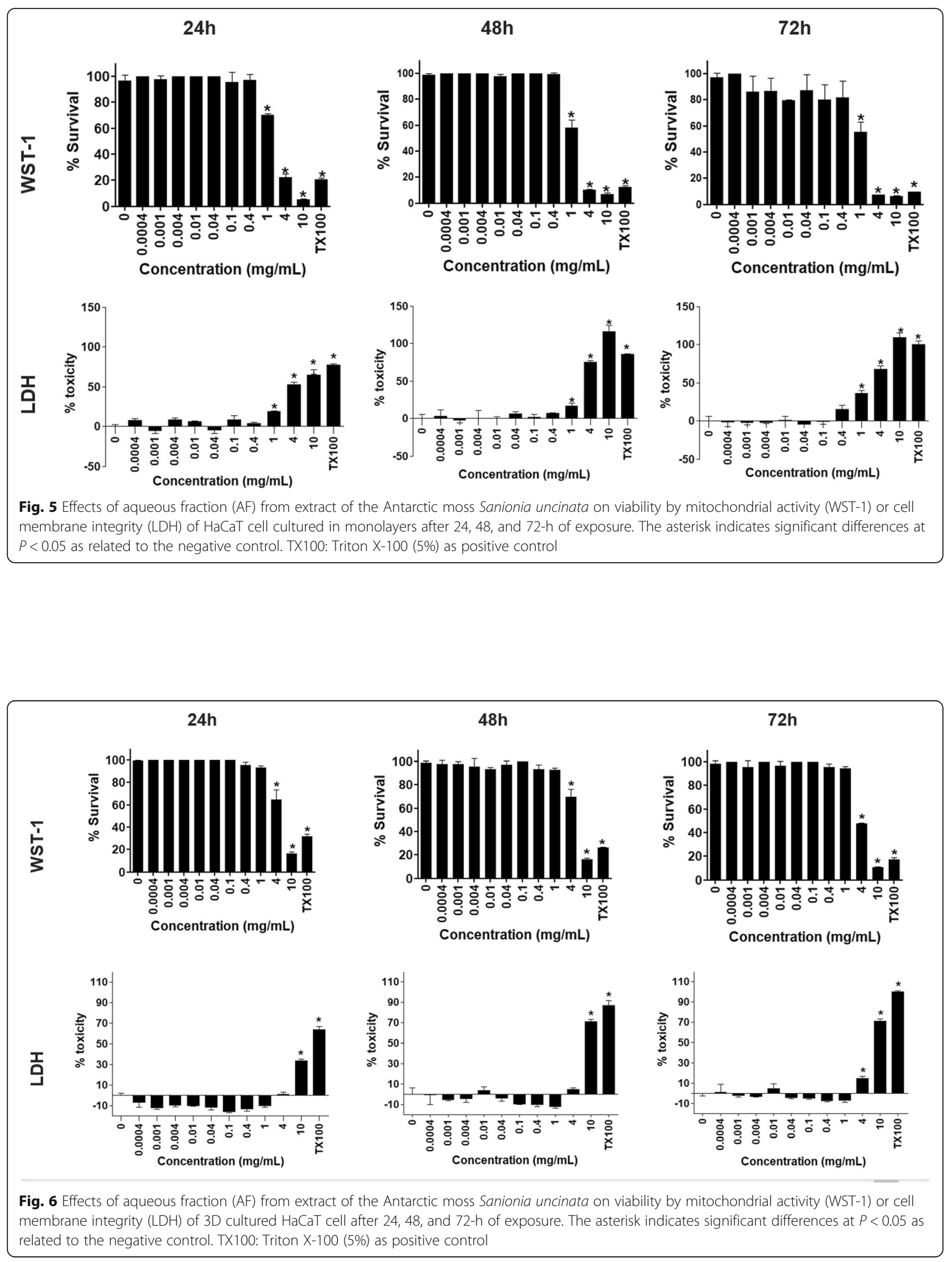
Table 2 Phototoxicity of isolated residual AF and its association with UV-filters (BP-3, OMC, OCT, MBC)

\begin{tabular}{lll}
\hline Substance & PIF & MPE \\
\hline AF & 1.089 & 0.035 \\
AF + BP-3 & 0.736 & -0.020 \\
AF + MBC & 1.377 & -0.046 \\
AF + OMC & 1.843 & 0.087 \\
AF + OCT & 0.142 & -0.321 \\
SLS (negative control) & 0.856 & -0.030 \\
Tetracycline (positive control) & $40.481^{\mathrm{a}}$ & $0.539^{\mathrm{a}}$
\end{tabular}

$A F$ aqueous fraction, $B P-3$ benzophenone-3, $O M C$ octyl-methoxycinnamate, $O C T$ octocrylene, $M B C$ and 3-(4-methylbenzylidene)-camphor, SLS sodium lauryl sulfate, PIF Photo-Irritation-Factor, MPE Mean Photo Effect, BP-3 (PIF: 1.798, MPE: 0.152); OMC (PIF: 1.741, MPE: 0.105); OCT (PIF: 0.618, MPE: -0.034), MBC (PIF: 0.112, MPE: -0.133)

${ }^{\text {a }}$ Classified as phototoxic

corroborate with the data obtained previously with HE using HPLC-DAD, in which flavonoids, including these classes, were characterized [14]. In plants, the flavonoids constitute an enormous class of phenolic natural products. Present in most plant tissues flavonoids such as quercetin derivatives and other dihydroxy B-ring substituted flavonoids are able of UV absorbing and scavenge UV-generated ROS to protecting plants from UV radiation of sun $[26,27]$. The $\lambda \max$ in visible spectrum $(>400 \mathrm{~nm})$ shown by the fraction can be from traces of chlorophylls ( 420 and $650 \mathrm{~nm}$ by additive absorption of chlorophyll a and chlorophyll b) and carotenoids $(500 \mathrm{~nm})$, both classes remaining of partition process since high content of these compound in mosses is known $[12,28]$.

In vitro SPF has been applied to be linear, precise, accurate, specific and robust [15]. In order to evaluated the photoprotection efficacy of AF by absorbing UVR at the erythemainductor region, the in vitro SPF was determined. Despite the low value of SPF obtained by AF alone, the SPF values of the UV-filters BP-3 and OMC, increased significantly $(P<0.05, t$ Student) when associated with AF. Recently our research group observed similar features for the different extracts of the Antarctic moss S. uncinata, including HE [14]. This suggests that the more polar character of the constituents of the HE leave to an increased intensity of band $K(\lambda \max 260 \mathrm{~nm}$, $\pi$-conjugated transition), causing the hyperchromic effect observed [29]. It is well documented that flavonoids and other phenol derivatives can also act in synergy with vitamin $\mathrm{C} / \mathrm{vita}$ min E, for example [30]. Natural compounds such as polyphenols can be more effective as sunscreens than synthetic chemicals, due to their long-term beneficial effects mainly against free radicals. In addition, today there is trend to develop high UV protection sunscreens using low concentrations of synthetic products [31], since chemical sunscreens have been reported for causing adverse secondary effects in human [7]. The same are known that UV-filters have the potential to cause abnormalities in development of zebrafish embryos [32]. In this sense, the embryotoxicity of the AF was investigated using the zebrafish as an organism model, by assessing their lethal and sublethal endpoints. The zebrafish early life-stage is an important model because offers a complex and multicellular system integrating the interaction of several tissues and differentiation processes [33] that permit drug screening and embryotoxicity assessment simultaneously [34]. Besides that, the transparency embryo and the development outside of the mother allow scoring of embryotoxic effects easily [34]. Our results showed that AF was not toxic to zebrafish early life stage. Besides, AF did not induce significantly lethal effects and malformations in zebrafish development and this fraction was not able to induce delay or embryo hatching inhibition. Thus, it seems AF have no embryotoxic potential. The gold standard for human application will remain mammals. However, employing zebrafish embryos at an early drug development stage could possibly reduce cost of new drugs significantly and will certainly provide an ethically more acceptable alternative to traditional testing [34].

Regarding the cytotoxic evaluation, the AF until $0.4 \mathrm{mg} /$ $\mathrm{mL}$ did not significantly affect the mitochondrial dehydrogenase activity, as detected by the WST-1 assay, in cultured in monolayers $\mathrm{HaCaT}$ cells. Similar results were obtained by the cell membrane integrity, as shown by the LDH activity assay. In 3D cell culture, an increased cell resistance to toxicity was observed, since cell viability of $\mathrm{HaCaT}$ by WST-1 and LDH measurement was above $90 \%$ when using $\leq 1$ and $4 \mathrm{mg} / \mathrm{mL}$, respectively, in all exposure times. Comparatively to conventional 2D cultures, 3D cell culture reproduces better the tissue architecture in vivo, does forecast organspecific toxicity and emulates more closely the biochemistry and mechanics of the microenvironment in tissues [23]. When exposed to a xenobiotic, the behavior of cells is related to tissue architecture. Likely, the difference in behavior between monolayer and in 3D cells may be associated with the spatial geometry and distribution of cells in both systems [35]. In spheroid cultures, grown within alginate scaffolds, as used in this work, HaCaT cells can secrete extracellular matrix and interact with cells from their original microenvironment [36]. Thus, this type of cell culture system might simulate in vivo processes, such as cell-cell contact, altered metabolism, variations in the cell cycle, and diffusion of nutrients, oxygen or xenobiotics [37]. Thus, the increased cell resistance to toxicity may be attributed to cell arrangement.

The 3T3 NRU phototoxicity assay, used as endpoint for phototoxic hazard, has showed high sensitivity and specificity [38]. It has been validated and accepted for regulatory purposes, obtaining a correlation of in vivo and in vitro results above $95 \%[39,40]$. AF demonstrated values of PIF $<2$ and MPE $<0.1$ (no phototoxicity), even though in combinations containing UV-filters such as BP-3, MBC, OMC and OCT. 


\section{Conclusions}

The current study has shown that the Antarctic moss $S$. uncinata contains important constituents for its protection against photobiological damage and the associated oxidative stresses. The compounds present in S. uncinata could have great potential for health, cosmetic and dermatological applications. The UV-visible analysis induced optical absorption spectra recorded in the UV-visible light spectra. The fraction showed enhanced SPF of BP-3 and OMC, indicating that its constituents could be considered as attractive candidates for protection against UV-induced erythema formation. Additionally, the AF did not induce phototoxic effects, even in combination with UV-filters. Despite cytotoxicity has been detected in the $\mathrm{HaCaT}$ cell cultured in monolayers, an increased cell resistance to toxicity was observed in 3D cell culture, suggesting that in this system, that more closely resembles in vivo cell growth, higher concentrations can be used without damage to the cell. Furthermore, the AF did not induce acute toxicity on zebrafish embryos, suggesting no embryotoxic potential. Therefore, the present study shows that residual AF presents a good potential for a skin photoprotection against UV-radiation.

\section{Abbreviations}

2D: Two dimensions; 3D: Three dimensions; AF: Aqueous fraction; $\mathrm{AU}(\lambda)$ : Absorbance; Bf: $n$-butanol fraction; BP-3: Benzophenone-3; CF: Correction factor; Df: Dichloromethane fraction; DMEM: Dulbecco's Modified Eagle's Medium; $E(\lambda)$ : Erythmogenic effect; EE: Ethanolic extract; Ef: Ethyl acetate fraction; FBS: Fetal bovine serum; FCB: Fetal calf serum; HE: Hydroethanolic extract; Hf: $n$-hexane fraction; LDH: Lactate dehydrogenase; MBC: 3-(4-methylbenzylidene)-camphor; ME: Methanolic extract; MPE: Mean Photo Effect; NR: Neutral red; NRU: Neutral red uptake OCT: Octocrylene; OMC: Octyl-methoxycinnamate; PIF: Photo-Irritation-Factor; ROS: Reactive oxygen species; SLS: Sodium lauryl sulfate; SPF: Sun protection factor; UVA: Ultraviolet A; UVB: Ultraviolet B; UVC: Ultraviolet C; UVR: Ultraviolet radiation; WST-1: Water-soluble tetrazolium salt; $I(\lambda)$ : Sunlight intensity

\section{Acknowledgements}

The authors wish to thank Dr. Antônio Batista Pereira from the Federal University of Pampa, Rio Grande do Sul (Brazil) for identifying the moss. We also thank PROANTAR and INCT-Criosfera for allowing sampling in Antarctica.

\section{About this supplement}

This article has been published as part of BMC Pharmacology and Toxicology Volume 20 Supplement 1, 2019: Proceedings of Toxi-Latin 2018. The full contents of the supplement are available online at https://bmcpharmacoltoxicol. biomedcentral.com/articles/supplements/volume-20-supplement-1.

\section{Authors' contributions}

ASF: designed the experiments, wrote the proposal, participated in data collection, analyzed and drafted the manuscript. LBB and GARO: participated in embryotoxicity study and drafted the manuscript. ERAF: participated in data analysis of 3D cultured and review of the manuscript; HE: participated in data collection and data analysis. JLM: interpreted the results and review the manuscript. IF: supervision, revision and interpretation. All authors reviewed literature and participated in the paper final version.

\section{Funding}

Publication costs are funded by CNPq 302345/2017-5 (Brasília, Brazil) and Faperj E26/202.256/2018 and E26/202.759/2017 (Rio de Janeiro, Brazil).

\section{Availability of data and materials}

The datasets generated and/or analyzed during the current study are available with the corresponding author on reasonable request.

Ethics approval and consent to participate

The fish embryo-larval protocol using zebrafish was approved by Ethics Committee on Animal Care of the Federal University of Goiás (UFG No. 102/2014).

Consent for publication

Not applicable.

\section{Competing interests}

The authors declare that they have no competing interests.

\section{Author details}

${ }^{1}$ Laboratory of Environmental Mutagenesis, Department of Biophysics and Biometry, University of the State of Rio de Janeiro, Rio de Janeiro, RJ, Brazil. ${ }^{2}$ Environmental Toxicology Research Laboratory (EnvTox), Faculty of Pharmacy, Federal University of Goiás (UFG), Goiânia, GO, Brazil. ²Laboratory of Toxicology, Department of Pharmacy and Pharmaceutical Administration, Pharmacy College, Fluminense Federal University, Niteroi, RJ, Brazil. ${ }^{4}$ Laboratory of Radioecology and Global Changes, Department of Biophysics and Biometry, University of the State of Rio de Janeiro, Rio de Janeiro, RJ, Brazil. ${ }^{5}$ Department of Natural Products, Institute of Drug Technology,

Oswaldo Cruz Foundation, Rio de Janeiro, RJ, Brazil.

Published: 19 December 2019

References

1. Uliasz A, Spencer JM. Chemoprevention of skin cancer and photoaging. Clin Dermatol. 2004;22(3):178-82. https://doi.org/10.1016/j.clindermatol. 2003.12.012.

2. Afaq F. Natural agents: cellular and molecular mechanisms of protection. Arch Biochem Biophys. 2011;508(2):144-51. https://doi.org/10.1016/j.abb. 2010.12.007

3. Bose B, Choudhury H, Tandon P, Kumaria S. Studies on secondary metabolite profiling, anti-inflammatory potential, in vitro photoprotective and skin-aging related enzyme inhibitory activities of Malaxis acuminata, a threatened orchid of nutraceutical importance. J Photochem Photobiol B. 2017;173:686-95. https://doi.org/10.1016/j.jphotobiol.2017.07.010.

4. Batista CM, Alves AVF, Queiroz LA, Lima BS, Filho RNP, Araújo AAS, de Albuquerque Júnior RLC, Cardoso JL. The photoprotective and antiinflammatory activity of red propolis extract in rats. J Photochem Photobiol B. 2018;180:198-207. https://doi.org/10.1016/j.jphotobiol.2018.01.028.

5. Nobile V, Michelotti A, Cestone E, Caturla N, Castillo J, Benavente-Garcia O, et al. Skin photoprotective and antiageing effects of a combination of rosemary (Rosmarinus officinalis) and grapefruit (Citrus paradisi) polyphenols. Food Nutr Res. 2016;60:31871. https://doi.org/10.3402/fnr.v60.31871.

6. Oca MK, Pearlman MRL, Mcclees SF, Strickland R, Afaq F. Phytochemicals for the prevention of photocarcinogenesis. Photochem Photobiol. 2017;93(4): 956-74. https://doi.org/10.1111/php.12711.

7. Mejía-Giraldo JC, Winkler R, Gallardo C, Sánchez-Zapata AM, Puertas-Mejía MA. Photoprotective potential of Baccharis antioquensis (Asteraceae) as natural sunscreen. Photochem Photobiol. 2016;92(5):742-52. https://doi.org/ 10.1111/php.12619.

8. Oliveira-Junior RG, Araújo CS, Souza GR, Almeida JRGS. In vitro antioxidant and photoprotective activities of dried extracts from Neoglaziovia variegata (Bromeliaceae). J Appl Pharm Sci. 2013;3(1):122-7. https://doi.org/10.7324/ JAPS.2013.30124.

9. González S, Fernández-Lorente M, Gilaberte-Calzada Y. The latest on skin photoprotection. Clin Dermatol. 2008;26(6):614-26. https://doi.org/10.1016/j. clindermatol.2007.09.010

10. Fernandes AS, Mazzei JL, Alencar AS, Evangelista H, Felzenszwalb I. Effects of Sanionia uncinata extracts in protecting against and inducing DNA cleavage by reactive oxygen species. Redox Rep. 2011;16(5):201-7. https://doi.org/10. 1179/1351000211Y.0000000011.

11. Thompson DWJ, Solomon S, Kushner JP, England MH, Grise KM, Karoly DJ. Signatures of the Antarctic ozone hole in southern hemisphere surface climate change. Nat Geosci. 2011;4:741-9. https://doi.org/10.1038/ NGEO1296. 
12. Lud D, Moerdijk TC, van de Poll WH, Bruma AG, Huiskes AH. DNA damage and photosynthesis in Antarctic and Arctic Sanionia uncinata (Hedw.) Loeske under ambient and enhanced levels of UV-B radiation. Plant Cell Environ. 2002;25(12):1579-89. https://doi.org/10.1046/j.1365-3040.2002. 00914.x.

13. Fernandes AS, Mazzei JL, Alencar AS, Evangelista H, Felzenszwalb I. Photoprotective and toxicological activities of extracts from the Antarctic moss Sanionia uncinata. Phcog Mag. 2015;11(41):38-43. https://doi.org/10, 4103/ 0973-1296.149701.

14. Fernandes AS, Mazzei JL, Oliveira CG, Evangelista H, Marques MRC, Ferraz ERA, et al. Protection against UV-induced toxicity and lack of mutagenicity of Antarctic Sanionia uncinata. Toxicology. 2017;376:126-36. https://doi.org/ 10.1016/j.tox.2016.05.021

15. Donglikar MM, Deore SL. Sunscreens: a review. Pharmacogn J. 2016;8(3):171-9.

16. Kaur CD, Saraf S. Photochemoprotective activity of alcoholic extract of Camellia sinensis. Int J Pharm. 2011;7(3):400-4. https://doi.org/10.3923/ijp.2011.

17. Mansur JS, Breder MN, Mansur MC, Azulay RD. Determination of sun protection factor by spectrophotometric methods. An Bras Dermatol. 1986;6:121-4.

18. Sayre RM, Agin PP, LeVee GJ, Marlowe E. A comparison of in vivo and in vitro testing of sunscreening formulas. Photochem Photobiol. 1979;29(3): 559-66. https://doi.org/10.1111/j.1751-1097.1979.tb07090.x.

19. Felzenszwalb I, Fernandes AS, Brito LB, Oliveira GAR, Silva PA, Arcanjo ME, et al. Toxicological evaluation of nail polish waste discarded in the environment. Environ Sci Pollut Res. 2018. https://doi.org/10.1007/s11356018-1880-y.

20. Organization for Economic Co-operation and Development-OECD. Test no. 236: Fish embryo acute toxicity (FET) test. Paris: OECD Publishing; 2013.

21. Kimmel CB, Ballard WW, Kimmel SR, Ullmann B, Schilling TF. Stages of embryonic development of the zebrafish. Dev Dyn. 1995;203(3):253-310. https://doi.org/10.1002/aja.1002030302.

22. Ferraz ERA, Zhaohui L, Boubriak O, Oliveira DP. Hepatotoxicity assessment of the azo dyes disperse orange 1, disperse red 1 and disperse red 13 using HepG2 cells in monolayer and in 3D. J Toxicol Environ Health A. 2012; 75(16-17):991-9. https://doi.org/10.1080/15287394.2012.696513.

23. Ferraz ERA, Rainho CR, Fernandes AS, Felzenszwalb I. Differential toxicity of an organic PM2.5 extract to human lung cells cultured in three dimensions (3D) and monolayers. J Toxicol Environ Health A. 2016;79(5):221-31. https:// doi.org/10.1080/15287394.2016.1143902.

24. Organization for Economic Co-operation and Development-OECD. Test no. 432: In Vitro 3T3 NRU phototoxicity test. Paris: OECD Publishing; 2004.

25. Fontana JD, Adelmann J, Passos M, Maraschin M, Lacerda CA, Lanças FM. Propolis: chemical micro-heterogeneity and bioactivity. New Jersey: Humana press; 2004. p. 203-18.

26. Verdaguer D, Jansen MAK, Llorens L, Morales LO. UV-A radiation effects on higher plants: exploring the known unknown. Plant Sci. 2017;255:72-81. https://doi.org/10.1016/j.plantsci.2016.11.014

27. Julkunen-Tiitto R, Nenadis N, Neugart S, Robson M, Agati G, Vepsäläinen J, et al. Assessing the response of plant flavonoids to UV radiation: an overview of appropriate techniques. Phytochem Rev. 2015;14(2):273-97. https://doi.org/10.1007/s11101-014-9362-4

28. Newham KK, Hodgson AW, Murray AWA, Peat HJ, Lewis Smith RI. Response of two Antarctic bryophytes to stratospheric ozone depletion. Global Change Biol. 2002;8:972-83. https://doi.org/10.1046/j.1365-2486.2002.00509.x.

29. Pretsch $E$, Bühlmann $P$, Affolter C. Structure determination of organic compounds, tables of spectral data. 3rd ed. Berlin: Springer-Verlag; 2000.

30. Guaratini T, Callejon DR, Pires DC, Lopes JNC, Lima LM, Neto DG, et al. Natural products derived sunscreen: market perspectives and interactions between business and research institutes. Quim Nova. 2009;32(3):717-21. https://doi.org/10.1590/S0100-40422009000300015.

31. Ramos MFS, Santos EP, Dellamora-Ortiz GM. Evaluation of antisolar activity and preliminary studies of photodegradation of Brazilian propolis. Rev Fitos. 2010;5(3):73-84

32. Fong $\mathrm{HCH}, \mathrm{Ho} \mathrm{JCH}$, Cheung AHY, Lai KP, Tse WKF. Developmental toxicity of the common UV filter, benzophenone-2, in zebrafish embryos. Chemosphere. 2016;164:413-20. https://doi.org/10.1016/j.chemosphere.2016.08.073.

33. Scholz S, Fischer S, Gündel U, Küster E, Luckenbach T, Voelker D. The zebrafish embryo model in environmental risk assessment - applications beyond acute toxicity testing. Environ Sci Pollut Res. 2008;15(5):394-404 https://doi.org/10.1007/s11356-008-0018-z.

34. Yang L, Ho NY, Alshut R, Legradi J, Weiss C, Reischl M, et al. Zebrafish embryos as models for embryotoxic and teratological effects of chemicals. Reprod Toxicol. 2009;28(2):245-53. https://doi.org/10.1016/j. reprotox.2009.04.013.

35. Pampaloni F, Stelzer E. Three-dimensional cell cultures in toxicology. Biotechnol Genet Eng Rev. 2009;26(1):117-38. https://doi.org/10.5661/bger26-117.

36. Fennema E, Rivron N, Rouwkema J, Blitterswijk CV, de Boer J. Spheroid culture as a tool for creating 3D complex tissues. Trends Biotechnol. 2013; 31(2):108-15. https://doi.org/10.1016/j.tibtech.2012.12.003.

37. Xu WH, Han M, Dong Q, Fu ZX, Diao YY, Liu H, et al. Doxorubicin-mediated radiosensitivity in multicellular spheroids from a lung cancer cell line is enhanced by composite micelle encapsulation. Int J Nanomedicine. 2012;7: 2661-71. https://doi.org/10.2147/IJN.S30445

38. Ceridono M, Tellner P, Bauer D, Barroso J, Alépée N, Corvi R, et al. The 3T3 neutral red uptake phototoxicity test: practical experience and implications for phototoxicity testing - the report of an ECVAM-EFPIA workshop. Regul Toxicol Pharmacol. 2012;63(3):480-8. https://doi.org/10.1016/j.yrtph.2012.06.001.

39. Vinardell MP, Benavides T, Mitjans M, Infante MR, Clapés P, Clothier R. Comparative evaluation of cytotoxicity and phototoxicity of mono and diacylglycerol amino acid-based surfactants. Food Chem Toxicol. 2008; 46(12):3837-41. https://doi.org/10.1016/j.fct.2008.10.007.

40. Lynch AM, Wilcox P. Review of the performance of the $3 T 3 \mathrm{NRU}$ in vitro phototoxicity assay in the pharmaceutical industry. Exp Toxicol Pathol. 2011; 63(3):209-14. https://doi.org/10.1016/j.etp.2009.12.001.

\section{Publisher's Note}

Springer Nature remains neutral with regard to jurisdictional claims in published maps and institutional affiliations.
Ready to submit your research? Choose BMC and benefit from:

- fast, convenient online submission

- thorough peer review by experienced researchers in your field

- rapid publication on acceptance

- support for research data, including large and complex data types

- gold Open Access which fosters wider collaboration and increased citations

- maximum visibility for your research: over $100 \mathrm{M}$ website views per year

At BMC, research is always in progress.

Learn more biomedcentral.com/submissions 